\title{
Sources of off-flavor in pangasius catfish (Pangasianodon hypophthalmus) ponds
}

\begin{abstract}
With the intensification of aquaculture system, off-flavor in cultured pangasius catfish (Pangasianodon hypophthalmus) has become a problem in Bangladesh, resulting in poor acceptability and reduced market price. Since water quality parameters and sediment have greater implications on fish quality, studies were undertaken to identify potential off-flavor agents by investigating water temperature, dissolved oxygen (DO) $\mathrm{pH}$, phytoplankton diversity and sediment organic carbon in 3 randomly selected ponds of 3 upazilain Mymensingh district viz., Sadar, Trishal and Muktagachha. Water temperature and DO was found to be significantly different in ponds of Trishalupazila along with significantly high sediment organic carbon $(\mathrm{p}<0.05)$. Correspondingly, the Algal Genus Pollution Index (AGPI) estimated to study the water quality revealed that ponds in this upazila has the highest organic nutrient level $(25.33 \pm 3.21)$. These values, along with strong positive correlation of cyanobacteria abundance and water temperature, sediment organic carbonindicate higher risk of off-flavor production in pond water. Adoption of proper management strategies need to taken immediately so that off-flavor producing organisms can be minimized. This will ensure higher acceptability of pangasius catfish produced in this region and safeguard livelihoods of the fish producers.
\end{abstract}

Keywords: off-flavor, cyanobacteria, pangasius catfish, pangasianodon hypophtalmus, fish breeding pond
Volume 10 Issue 3 - 2021

\author{
Atiar Rahman,' Mohammed Nurul Absar \\ Khan, ${ }^{2}$ Kamal,' Shaheed Reza' \\ 'Department of Fisheries Technology, Bangladesh Agricultural \\ University, Bangladesh \\ ${ }^{2}$ Department of Fishing and Post-Harvest Technology, \\ Chattogram Veterinary and Animal Sciences University, \\ Bangladesh
}

\author{
Correspondence: Shaheed Reza, Department of \\ Fisheries Technology, Bangladesh Agricultural University, \\ Mymensingh-2202, Bangladesh, Fax +880 91 61510, \\ Emailmsreza@bau.edu.bd
}

Received: April 29, 2021 | Published: August 04, 2021

\section{Introduction}

Aquaculture is one of the fastest growing food-production sector in the world and currently serves to meet majority of the demand for animal protein. ${ }^{1}$ With the growing world population in one hand and depleting stock of marine water bodies on the other, freshwater and marine aquaculture has contributed to the impressive growth in the seafood supply for human consumption. ${ }^{2}$ However, due to intensification of the culture systems, objectionable odors or tastes, sometimes referred to as 'off-flavor', are detected in aquaculture products that develop in fish before harvest. ${ }^{3}$ It reduces taste and palatability of the fishery products. ${ }^{4}$ Such off-flavors are mainly related to the diet of the cultured animal, particularly in catfish farms, environmental and/or caused by inadequate management strategies. ${ }^{5}$ It was reported that off-flavor in fish results from two compounds, geosmin [trans-1, 10,-dimethyl-trans-(9)-decalol] and 2-methylisoborneol (exo-1, 2, 7, 7-tetramethyl-[2.2.1] heptan-2-ol), and these compounds are attributed with having an 'earthy' and 'musty' odor, respectively. ${ }^{6}$ In aquaculture systems, earthy and musty off-flavors have been detected in common carp, ${ }^{7}$ catfish, ${ }^{8}$ shrimp ${ }^{9}$ and tilapia. ${ }^{10}$ Some pre-harvest off-flavors are caused by substances in the diet that are absorbed across the gastrointestinal tract. ${ }^{11}$ Although dietrelated off-flavors are rare in fish fed, pond-raised catfish occasionally eat other foods, and some of those may cause flavor problems. Other pre-harvest flavor problems are caused by odorous compounds produced by naturally occurring aquatic primary producers like microphytes, microorganisms like cyanobacteria. ${ }^{12,13}$ The compounds are synthesized by algae or bacteria, released into the water, and then absorbed through the gills, skin or gastrointestinal tract of fish. ${ }^{14}$ The resulting off-odors/flavors decrease profit margins for producers because processing must be delayed until the off-odor/flavor is absent.

During the last couple of decades, fish production from freshwater aquaculture sector in Bangladesh has been gradually increasing. The annual growth rates of production indicate that inland aquaculture grew fastest, followed by the marine sector. ${ }^{15}$ It is estimated that roughly equal quantities of fish are produced in three culture systems - around 395,000 tonnes each from traditional homestead ponds, commercial semi-intensive culture of carps, and pellet-fed intensive systems (mainly pangasius catfish and tilapia). Sometimes the ponds are rainfed and their sizes vary depending on areas. In Bangladesh, there are 4.65 million ha inland water whereas 528,390 ha closed water which are used for fisheries production. ${ }^{15,16}$ Among total inland open water, most of the water bodies are taken under farming practices and aquaculture currently fulfills $60 \%$ of total animal protein of national demand. Fish farming especially pangasius catfish farming is adopted throughout the region not only for suitable environmental condition for farming but also for its benefits and demand in the market. Now-adays, pangasius catfish farming has become most popular among the farmers and its annual production is 453,383 tonnes, which represent about $12.52 \%$ of aquaculture production. ${ }^{15}$ Mymensingh district is the most prominent area among the fish producing areas of Bangladesh and popularly called 'Mecca of Aquaculture in Bangladesh'. The sub-districts (officially known as 'upazila') of Mymensingh alone produces some $40 \%$ of aquaculture product of Bangladesh. ${ }^{15}$ However, due to the unawareness among the farmers about the effect of water quality in terms of pollution and sediment chemistry, consumers are complaining about that fish produced in Trishalupazila and its vicinity possess off-flavor. Therefore, it became essential to identify causative agents of such off-flavor so that the farmers can take necessary steps to minimize such problems in pangasius catfish ponds. The present study was, therefore, conducted for addressing the above existing problems with the following objectives: (i) collect information on the physico-chemical parameters of water and sediment in pangasius catfish ponds; (ii) identify the probable causes of water quality deterioration; and (iii) suggest guidelines for preventing the off-flavor problem in catfish ponds. 


\section{Materials and methods}

\section{Study site}

The study was carried out at the farmer's ponds located at 3 upazila (Sadar, Trishal and Muktagachha)in Mymensingh district during May-June 2013 (Figure 1). These upazila were purposively selected as they produce the largest share of pangasius catfish of the country. Area of each pond was about $800 \mathrm{~m}^{2}$ with an average depth of $1.8 \pm 0.1 \mathrm{~m}$ depth with a stocking density of $400-450 /$ decimal with a feeding frequency of three. The ponds were rain fed and had facilities to supply water from deep tube-well.

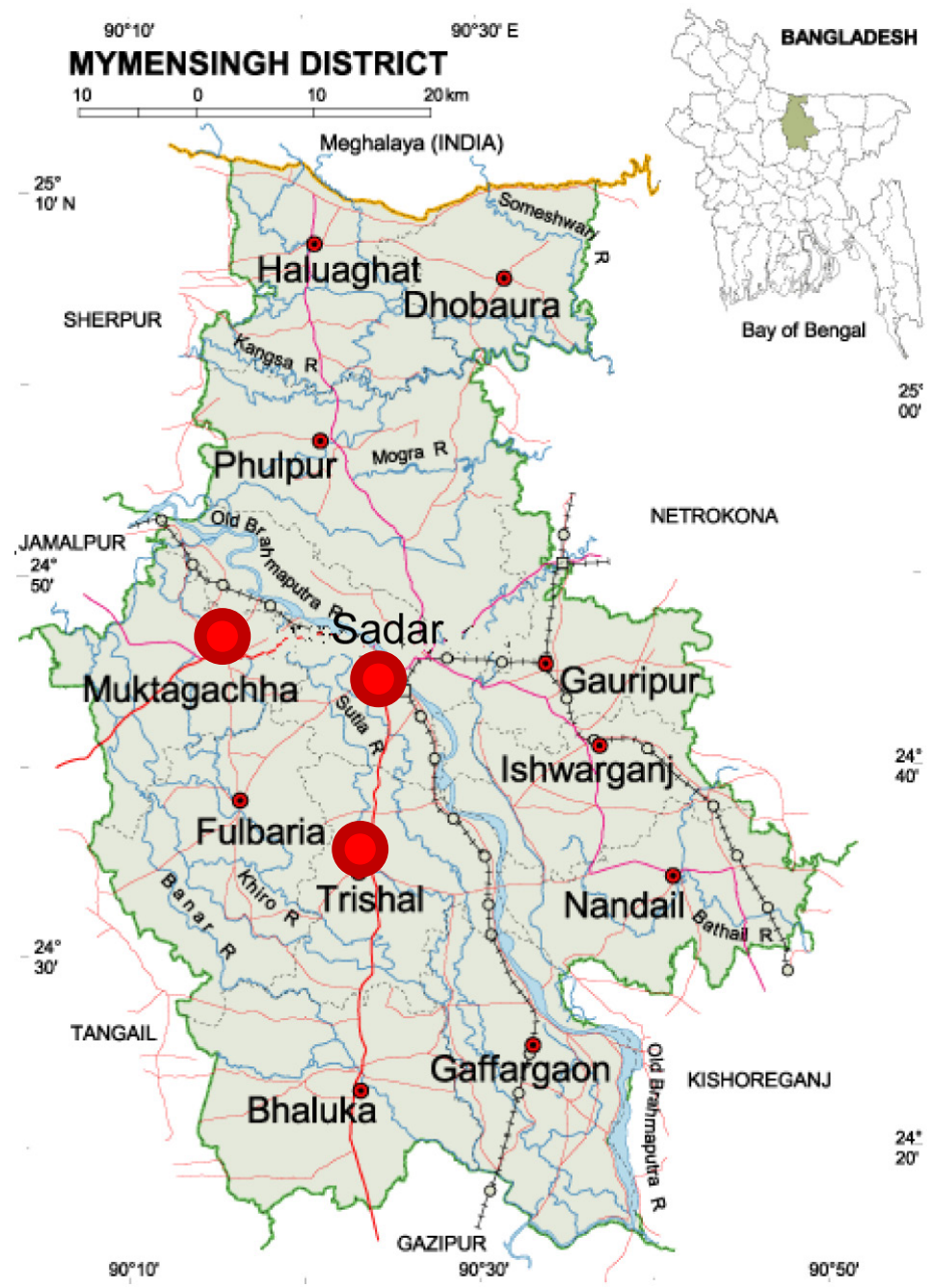

Figure I Map showing location of the study area at Sadar, Muktagachha and Trishalupazilas of Mymensingh district (Source: Banglapedia).

\section{Determination of water quality variables}

Water sample collection were made between 9.00 and $11.00 \mathrm{am}$, on each sampling day. For this purpose, a number of clear $500 \mathrm{ml}$ black bottles marked with pond number and sampling date were used for collection of water samples. Water samples were collected from all layers (upper, middle and bottom) of the water column. Then, samples were taken in the vial immediately at the site. Temperature $\left(\mathrm{T}^{\circ} \mathrm{C}\right.$; thermometer, div., $\left.0.1^{\circ} \mathrm{C}\right)$, dissolved oxygen (DO), nitrate-nitrogen $\left(\mathrm{NO}_{3}-\mathrm{N}\right)$, ammonia-nitrogen $\left(\mathrm{NH}_{4}-\mathrm{N}\right)$ and $\mathrm{pH}$ ( $\mathrm{pH}$-meter Hanna Instruments, Germany)from each pond were recorded. DO, $\mathrm{NO}_{3}-\mathrm{NandNH}_{4}$-Nweremeasured using HANNA Test kit, Hanna Instruments.

\section{Collection of microphytes and preservation in formaldehyde solution}

Microphytes, the primary producers suspended in the pelagic zone of the pond were collected from each pond and used for plankton monitoring as described elsewhere. ${ }^{7} 5 \mathrm{~L}$ of surface water was taken from different places of the pond and passed through fine mesh $(25 \mu \mathrm{m})$ plankton net. Filtered samples were taken into a measuring cylinder and carefully made up to a standard volume of $50 \mathrm{ml}$. The collected plankton samples were preserved in 5\% buffered formalin and brought to the Pond Dynamics Laboratory, Department of Fisheries Management, Bangladesh Agricultural University (BAU), Bangladesh. From each $50 \mathrm{ml}$ preserved sample, $1 \mathrm{ml}$ sub-sample was examined by using a Sedge Wick-Rafter cell (S-R cell) and a biological microscope (Model CH40, Olympus Optical Co. Ltd., Tokyo, Japan) with phase contrast facilities. For each pond, mean number of plankton was recorded and expressed numerically per liter of water. The quantitative estimation of the planktons was done by using the following formula and expressed numerically per liter of water.

$$
\mathrm{N}=\frac{\mathrm{A} \times 1000 \times \mathrm{C}}{\mathrm{V} \times \mathrm{F} \times \mathrm{L}}
$$


where: $\mathrm{N}$, number of plankton cells or units per liter of original water, A, total number of plankton counted; $\mathrm{C}$, volume of final concentrate of the sample in $\mathrm{ml} ; \mathrm{V}$, volume of field in cubic $\mathrm{mm} ; \mathrm{F}$, number of field counted; $\mathrm{L}$, volume of original water in liter.

\section{Calculation of algal genus pollution index (AGPI)}

Algal genus pollution index (AGPI) is a useful parameter that shows organic pollution level of a water body. Palmer ${ }^{18}$ assigned a pollution index factor of 1 through 5 to each of the 20 types of algae that are most tolerant to organic pollution. Based on this, pollution index was assigned to each phytoplankton genera (considering $>50$ cells $/ \mathrm{ml}$ )to calculate the AGPI for pangasius catfish ponds.

\section{Collection, treatment and analysis of pond sediment}

Samples of bottom sediment was collected from each pond with the help of an Ekman Dredge (covering an area of $225 \mathrm{~cm}$ ), which was designed to trap normally a sediment column of $5-10 \mathrm{~cm}$ depth from the sediment water interface area. Triplicate sediment samples from three locations were collected from each pond. Each sediment sample was put in a labelled plastic bag and carried to the laboratory at BAU. In the laboratory, the sediment samples were thoroughly mixed up, stretched out on polythene papers and left for air drying for overnight at room temperature. The dried sediments were ground finely, sieved through a $0.03 \mathrm{~mm}$ meshed brass sieve and kept properly in labelled polythene bag. Organic carbon analysis of sediment samples was conducted at BAU Humboldt Soil Test laboratory, Department of Soil science, BAU.

\section{Data analysis}

One-way ANOVA was carried out to test the significant variations between the cases. Correlation analysis was done to determine the positive or negative relationships between the quality factor of water and sediment of fish ponds. All data were analyzed by SPSS version 11.5 (Chicago. USA). Significant differences were determined among treatments at the $5 \%$ level $(\mathrm{p}<0.05)$.

\section{Results}

\section{Physico-chemical variables of pond water}

The variation of pond water temperature at three upazilain Mymensingh districts showed the highest temperature for ponds located at Trishal upazila $\left(27.7 \pm 0.6^{\circ} \mathrm{C}\right)$ and lowest in Sadar upazila $\left(24.7 \pm 1.0^{\circ} \mathrm{C}\right)$. According to statistical analysis, Sadar upazila ponds had significantly low temperature compared to other ponds, in Trishal and Muktagachha upazila $(\mathrm{p}<0.05)$. DO level was recorded that varied from 2.5 to $5.8 \mathrm{mg} / 1$ in 9culture ponds with significantly lower levels in Trishal upazila ponds. During the study period, the values of $\mathrm{pH}$ ranged from 6.6 to 6.8 with highest in Trishal upazila and lowest in Sadar. These values did not vary significantly, indicating a homogeneous level of alkalinity across ponds in Mymensingh district.

\section{Organic carbon in pond sediment}

In the present study, sediment organic carbon range was 1.07 to $2.35 \%$ for ponds located at Sadar, Trishal and Muktagachha upazila (Table 1). The highest organic carbon was recorded in the ponds of Trishal upazila $(2.35 \pm 0.14 \%)$ and the lowest was recorded in the ponds of Muktagachha upazila $(1.07 \pm 0.41 \%)$ with significantly high concentration in ponds of Trishal upazila $(\mathrm{p}<0.05)$.

\section{Microphyte populations in pond water}

Microphytes of a fish pond represent the primary production of the water body, contributing substantially towards the succession and dynamics of zooplankton and fish. Table 2 shows the microphyte genera observed in 9pangasius catfish ponds in Mymensingh district. During the study, four major classes were identified with most of them to be common in all the ponds. In Sadarupazila, the most common genera were Anabaena, Euglena, Closterium, Cyclotella, Tetraedon, Phacus etc. In Trishal, the most common phytoplankton were Volvox, Aphanizomenon, Ankistrodesmus, Chlorella, Scenedesmus, Euglena and Anabaena, while in Muktagachha upazila, Spirulina, Cosmarium, Cyclotella, Scenedesmus, Tetraedon, Microcystis, Stichococcus, Tabellaria, Chlorella, Cyclotella and Closterium were dominant.

Table I Physico-chemical parameters of water and sediments of pangasius catfish ponds at three upazila in Mymensingh

\begin{tabular}{lllll}
\hline Parameter & Sadar & Trishal & Muktagachha & Level of Significance \\
\hline Water parameter & & & & \\
Temperature $\left({ }^{\circ} \mathrm{C}\right)$ & $24.7 \pm 1.0^{\mathrm{b}}$ & $27.7 \pm 0.6^{\mathrm{a}}$ & $27.0 \pm 1.0^{\mathrm{a}}$ & $*$ \\
$\mathrm{DO}$ & $5.8 \pm 0.1^{\mathrm{a}}$ & $2.5 \pm 0.4^{\mathrm{b}}$ & $4.8 \pm 0.2^{\mathrm{a}}$ & $*$ \\
$\mathrm{pH}$ & $6.6 \pm 0.1^{*}$ & $6.8 \pm 0.0$ & $6.8 \pm 0.1$ & $\mathrm{~N}$ \\
Sediment parameter & & & & \\
Organic carbon $(\%)$ & $2.0 \pm 0.53^{\mathrm{a}}$ & $2.35 \pm 0.14^{\mathrm{a}}$ & $1.07 \pm 0.42^{\mathrm{b}}$ & $*$ \\
\hline
\end{tabular}

"Significantly different $(\mathrm{p}<0.05)$; NS, non-significant

Table 2 List of phytoplankton genera observed in water of pangasius catfish ponds at three upazila in Mymensingh

\begin{tabular}{lll}
\hline Upazila & Pond no. & Phytoplankton genera \\
\hline Sadar & 1 & $\begin{array}{l}\text { Cyclotella, Tetraedon, Anabaena, Aphanizomenon, Ankistrodesmus, Chlorella, Scenedesmus, Volvox, Nitszchia, } \\
\text { Oscillatoria, Surirella } \\
\text { Cyclotella, Euglena, Anabaena, Tetraedon, Soirulina, Ankistrodesmus, Chlorella, Cosmarium, Scenedesmus, } \\
\text { Pediastrun, Nitszchia, Surirella } \\
\text { Stichococcus, Tabellaria, Euglena, Cyclotella, Nitszchia, Cosmarium, Cyclotella, Ankistrodesmus, Anabaena, Surirella, } \\
\text { Hildenbnandia, Oscillatoria }\end{array}$ \\
\hline
\end{tabular}


Table Continued...

\begin{tabular}{|c|c|c|}
\hline Upazila & Pond no. & Phytoplankton genera \\
\hline \multirow{3}{*}{ Trishal } & I & $\begin{array}{l}\text { Actinastrum, Anabaena, Ankistrodesmus, Aphanizomenon, Chorella, } \\
\text { Closterium, Cosmarium, Cyclotella, Euglena, Gomphosphaeria, Hildenbrandia, Nitszchia, Oscillatoria, Scenedesmus, } \\
\text { Stichococcus, Surirella, Volvox }\end{array}$ \\
\hline & 2 & $\begin{array}{l}\text { Pediastrun, Cosmarium, Ankistrodesmus, Chlorella, Tetraedon, Cyclotella, Euglena, Nitszchia, Phacus, Closterium, } \\
\text { Anabaena, Scenedesmus, Tetraedon, Navicula, Oscillatoria, Hildenbnandia, Pleurococcus }\end{array}$ \\
\hline & 3 & $\begin{array}{l}\text { Anabaena, Cosmarium, Closterium, Euglena, Chlorella, Scenedesmus, Soirulina, Oscillatoria, Tetraedon, Phacus, } \\
\text { Trachelomonas, Stichococcus, Nitszchia, Hildenbrandia, Pleurococcus }\end{array}$ \\
\hline \multirow{3}{*}{ Muktagachha } & I & $\begin{array}{l}\text { Euglena, Flagellaria, Stichococcus, Chlorella, Microcystis, Ankistrodesmus, Closterium, Spirulina, Volvox, Surirella, } \\
\text { Oscillatoria, Cosmarium, Aphanizomenon, Pediastrun, Cyclotella, Anabaena, Phacus }\end{array}$ \\
\hline & 2 & Cosmarium, Cyclotella, Chlorella, Oscillatoria, Euglena, Scenedesmus, Tetraedon, Closterium, Microcystis \\
\hline & 3 & $\begin{array}{l}\text { Stichococcus, Tabellaria, Chlorella, Cyclotella, Closterium, Oscillatoria, Tetraedon, Euglena, Microcystis, Spirulina, } \\
\text { Nitszchia, Ankistrodesmus, Anabaena, Cosmarium }\end{array}$ \\
\hline
\end{tabular}

Table 3 shows the abundance of these microphytepopulations. The abundance of the group Cyanobacteria ranged from $13.69 \pm 1.5 \times 10^{4}$ to $10.23 \pm 2.5 \times 10^{4} \mathrm{cell} / \mathrm{s} /$ lof water with highest in Trishal and lowest in Sadar upazila. The abundance of Bacillariophyceae, Chlorophyceae and Euglenophyceae were $5.51 \pm 2.3 \times 10^{4}$ to $9.49 \pm 2.5 \times 10^{4}$ cells $/$, $6.61 \pm 1.5 \times 10^{4}$ to $10.19 \pm 3.5 \times 10^{4} \quad$ cells/land $5.48 \pm 1.5 \times 10^{4}$ to $7.11 \pm 1.5 \times 10^{4}$ cells $/ 1$, respectively. These results suggest that the density of microphytesis variable among aquaculture ponds. When the differences in their abundance was considered, the group
Cyanophyceae was found to be significantly higher in ponds of Trishal compared to Sadar and Muktagachha upazilas $(\mathrm{p}<0.05)$. Bacillariophyceae, on the other hand,weresignificantly lower in ponds of Trishal upazila compared to other locations $(\mathrm{p}<0.05)$. Chlorophyceae werealso found to be significantly lower in Sadar upazila compared to other two upazilas. However, there was no significant variation in Euglenophyceae among the ponds located at three upazillas.

Table 3 Abundance of phytoplankton genera observed in water of pangasius catfish ponds at three upazila in Mymensingh

\begin{tabular}{|c|c|c|c|c|}
\hline \multirow{2}{*}{ Area } & \multicolumn{4}{|c|}{ Plankton abundance $\left(\times 10^{4} \mathrm{cells} / \mathrm{L}\right)$} \\
\hline & Cyanophyceae & Bacillariophyceae & Chlorophyceae & Euglenophyceae \\
\hline Sadar & $10.23 \pm 2.5^{\mathrm{a}}$ & $8.89 \pm 2.5^{a}$ & $6.61 \pm 1.5^{a}$ & $7.11 \pm 1.5$ \\
\hline Trishal & $13.69 \pm 1.5^{b}$ & $5.5 \mathrm{I} \pm 2.3^{\mathrm{b}}$ & $9.27 \pm 2.5^{b}$ & $6.92 \pm 1.5$ \\
\hline Muktagachha & $12.00 \pm 1.3^{\mathrm{a}}$ & $9.49 \pm 2.5^{\mathrm{a}}$ & $10.19 \pm 3.5^{b}$ & $5.48 \pm 1.5$ \\
\hline
\end{tabular}

Values are mean $( \pm S D), n=3$; Means within each column sharing different upper case were significantly different $(p<0.05)$

\section{Relationship between physico-chemical parameters of water-sediment and microphyte groups}

In the present study, high abundance of Anabaena, Aphanizomenon was observed across all pangasius catfish ponds studied. We tried to correlate the abundance of microphyte groups with physico-chemical parameters of water and organic carbon of sediment. It was found that the abundance of Cyanophyceae was correlated well with water temperature $(\mathrm{r}=0.89, \mathrm{p}=0.01)$. On the other hand, the abundance of Cyanophyceae showed slight correlation with sediment organic carbon $(\mathrm{r}=0.61, \mathrm{p}=0.02)$ (Table 4).

\section{Relationship between water-sediment parameters and AGPI}

Table 5 shows the AGPI values of pangasius catfish ponds in three upazila ponds. It was revealed that pollution index scores for catfish ponds in Sadar, Trishal and Muktagachha were 17.33, 25.33 and 19.33 with lowest in ponds located at Sadar and highest in those located at Trishalupazila. The latter ponds fall into 'high organic pollution' category (AGPI $=25.33 \pm 3.21)$ while ponds in Sadar $(17.33 \pm 1.15)$ and Muktagachha $(19.33 \pm 0.58)$ were judged to be in 'probable high organic pollution' category.

Table 4 Correlation coefficient between physico-chemical parameters of water-sediment and abundance of Cyanophyceae in pangasius catfish ponds for three ponds of Trishalupazila in Mymensingh

\begin{tabular}{ll}
\hline Parameter & Plankton abundance \\
\hline Water temperature & $0.89(p=0.01)$ \\
Sediment Organic carbon & $0.61(p=0.02)$ \\
\hline
\end{tabular}


Table 5 Pollution index of algal genera observed in water of pangasius catfish ponds at three upazila in Mymensingh according to Palmer (I969)

\begin{tabular}{|c|c|c|c|c|c|c|c|c|c|c|}
\hline \multirow{2}{*}{ Algal genus } & \multirow{2}{*}{ Pollution index } & \multicolumn{3}{|l|}{ Sadar } & \multicolumn{3}{|l|}{ Trishal } & \multicolumn{3}{|c|}{ Muktagachha } \\
\hline & & Pond I & Pond 2 & Pond 3 & Pond I & Pond 2 & Pond 3 & Pond I & Pond 2 & Pond 3 \\
\hline \multicolumn{11}{|l|}{ Cyanophyceae } \\
\hline Oscillatoria & 5 & 5 & & 5 & 5 & 5 & 5 & 5 & 5 & 5 \\
\hline \multicolumn{11}{|l|}{ Chlorophyceae } \\
\hline Ankistrodesmus & 2 & 2 & 2 & 2 & 2 & 2 & & 2 & & 2 \\
\hline Chorella & 3 & 3 & 3 & & 3 & 3 & 3 & 3 & 3 & 3 \\
\hline Closterium & 1 & & & & 1 & I & I & I & I & 1 \\
\hline Scenedesmus & 4 & 4 & 4 & & 4 & 4 & 4 & & 4 & \\
\hline \multicolumn{11}{|l|}{ Bacillariophyceae } \\
\hline Nitszchia & 3 & 3 & 3 & 3 & 3 & 3 & 3 & & & 3 \\
\hline Cyclotella & 1 & I & 1 & 1 & 1 & 1 & & I & 1 & 1 \\
\hline Navicula & 3 & & & & & 3 & & & & \\
\hline \multicolumn{11}{|l|}{ Euglenophyceae } \\
\hline Euglena & 5 & & 5 & 5 & 5 & 5 & 5 & 5 & 5 & 5 \\
\hline Phacus & 2 & & & & & 2 & 2 & 2 & & \\
\hline $\begin{array}{l}\text { Score } \\
\text { (Average } \pm S D)\end{array}$ & & \multicolumn{3}{|c|}{$17.33 \pm 1.15^{\mathrm{a}}$} & \multicolumn{3}{|c|}{$25.33 \pm 3.2 \mathrm{I}^{\mathrm{b}}$} & \multicolumn{3}{|c|}{$19.33 \pm 0.58^{\mathrm{a}}$} \\
\hline
\end{tabular}

"Pollution classification: 0-10, lack of organic pollution; 10-15, moderate pollution; 15-20, probable high organic pollution; 20 or more, high organic pollution; Means within each row sharing different upper case were significantly different $(p<0.05)$

\section{Discussion}

One of the most important sources of off-flavor in fish is the surrounding environment in which fish is being cultured. These preharvest flavors develop during the grow-out period Multitude of biological processes in the pond water are responsible for development of these objectionable flavor, making the fish less acceptable to the consumer. Generally, the physico-chemical parameters of water greatly influence fish health and overall production in aquaculture systems. It closely interacts with the sediment properties as well. It is, therefore, important to determine temperature, $\mathrm{DO}, \mathrm{pH}$ of water, organic carbon of the sediment and odor producing microphytes to identify the sources of off-flavor in catfish pond.

P. hypophthalmus is generally considered as a hardy fish that can tolerate a wide range of environmental conditions. Temperature between $28-32^{\circ} \mathrm{C}$ is considered optimal for the species, with $34^{\circ} \mathrm{C}$ being the best culture temperature. ${ }^{19}$ In culture ponds, temperature greatly influences the growth and survival of all organisms including microphytes and various microorganisms. Since the average water depth of pangasius catfish ponds in Mymensingh region is $1.8 \pm 0.1 \mathrm{~m}$, it is expected that a steady temperature would remain in the pond during different phases of the day. In the present study, we recorded a temperature range between $24.7 \pm 1.0$ and $27.7 \pm 0.6^{\circ} \mathrm{C}$ in ponds of 3 upazila in Mymensingh district where ponds in Sadarupazila had significantly low temperature compared to other ponds. Still, these values were more or less similar to Roy. ${ }^{20}$ This last study recorded some physico-chemical parameters in nine experimental ponds of Fisheries Faculty, Bangladesh Agricultural University, Mymensingh during November, 2000 to October, 2001. He stated that water temperature varied from 22 to $32^{\circ} \mathrm{C}$, DO from 5.0 to $7.5 \mathrm{mg} / 1$ and $\mathrm{pH}$ from 7.5 to 8.5 . Usually, water temperature is lower in culture ponds during the early morning that gradually increases at noon throughout the afternoon. ${ }^{21}$ In the present study, water temperature was measured in the morning period of early summer. It may be expected that temperature would rise to an addition of 3 to $5^{\circ} \mathrm{C}$ during the later parts of the day. These results due to diurnal temperature variation and caused by multiple reasons including cloud cover, land use change, aerosols, water vapor and greenhouse gases. ${ }^{22}$ In case of DO, the values ranged between $2.5 \pm 0.4$ and $5.8 \pm 0.1 \mathrm{mg} / 1$, with significantly lower levels in ponds at Trishal upazila. The low DO values in ponds at Trishal upazila may be related to higher water temperature of the pond water. As solubility of $\mathrm{O}_{2}$ decreases as water temperature increases, indicating an inverse relationship between DO and water temperature, there is a high risk of stress for pangasius catfish with a low level of DO in pond water. At the same time, all living organisms in the pond might be influenced greatly due to such low DO level. In culture ponds, $\mathrm{pH}$ may vary between 6.5 to 8.2 due to environmental factors, such as breathing and photosynthesis, or pollution. The level of $\mathrm{pH}$ observed in the present study ranged between $6.6 \pm 0.1$ and $6.8 \pm 0.1$ that showed no significant difference among ponds of 3 upazila. Although the $\mathrm{pH}$ level slightly below 7.0 is considered unfavorable for many aquaculture species, tropical fishes like tilapia and pangasius catfish can tolerate and grow ideally between 6 and $9,{ }^{23}$ indicating suitable water chemistry for optimal fish growth.

It is well known that water quality is directly related to sediment chemistry. Attempts were, therefore, made to determine the organic carbon content in pond sediment which is thought be formed due to decomposition of pond elements like macroalgae and/or microorganisms, dejections of farmed fish, etc.

In the present study, sediment organic carbon ranged between 1.07 to $2.35 \%$ for ponds located at 3 upazila where significantly high 
concentration was observed in ponds of Trishal upazila $(\mathrm{p}<0.05)$ This higher accumulation of organic carbon in the sediment can be attributed to high nutrient concentrations, comparably high levels of soil particulate transfer from adjacent land, and high rates of preservation due to nearly continuous sediment anoxia. ${ }^{24,25}$ Generally, pangasius catfish are cultured at a high density in Mymen singh district where as high as 400-450 individuals/decimal are reared in earthen ponds. An estimation of total nitrogen utilization by this fish species showed that nearly $70 \%$ of total nitrogen supplied through the feed remains unused and gets deposited at the bottom ${ }^{26}$ and dissolved in the water column. This increases the chance of increased deposition of organic matter in the pond sediment. Boyd ${ }^{27}$ stated that pond sediment was not only source of nutrient but also had biological filtering ability, by adsorbing organic residues of feed, fecal matters of fish and algal metabolites which were generally toxic for fish, while Mayer and Telford ${ }^{28}$ reported that aerobic decomposition of organic matter for nutrient generation was the dominant mechanism, which released nutrient to the water column. It is, therefore, predicted that the relatively faster deposition of organic matter at the bottom was going through slow decomposition since DO levels were relatively low in water. Thisresulted in differences in the carbon capture function of different ponds. ${ }^{29}$

Among the various groups of primary producers in a fish pond, the small planktonic organisms suspended in the upper zone, i.e., microphytes show changes according to the environmental variables and pollution ${ }^{18,31}$ reported that a number of microphyte species is unable to tolerate slightest of pollution while few species may able to persist or even attain greater abundance under same situation. Attempts were, therefore, made to identify these assemblages up to genus level using microscopic observations. Overall, under 4 classes, 28 genera were identified, of which Anabaena, Ankistrodesmus, Chlorella, Euglena, Closterium, Cyclotella, Nitszchia, Oscillatoria, Scenedesmus and Tetraedon were the most common. Cyanobacteriaand Bacillariophyceae were also abundant andsignificantly higher in Trishal upazilaponds, while only Chlorophyceae showed high concentrationsin Muktagachha. The changes in distribution and abundance are thought to be linked to alteration of physico-chemical factors of pond water. ${ }^{32}$ Previous studies showed that species of Aphanizomenon, Oscillatoria, and Pseudanabaena from catfish aquaculture ponds produce 2-methylisoborneol. ${ }^{33}$ Geosmin and 2-methylisoborneol are also responsible for many of the off-flavor episodes/problems in municipal drinking water systems worldwide. ${ }^{13}$ Due to significantly higher abundance of cyanobacteria and a number of off-flavor producing plankton in pangasius catfish ponds of Trishal upazila, it is plausible that catfish grown in these ponds would possess off-flavor. This has created an environment favorable for offflavor development in catfish ponds particularly in Trishal upazila. However, several phytoplankton genera like Chlorella, Closterium, Nitszchia and Phacus were found to be least affected by the variation of measured physico-chemical factors. Off-flavor during pre-harvest does not pose a direct threat to fish health but adversely affects the acceptability of fish. This eventually causes delays in harvesting and increases production cost as depuration might be required to reverse the process of deposition of flavor compounds in fish body. Cyanobacteria have been reported to cause off-flavors and cannot be seen with the unaided eye. The cyanobacterial genera that have been associated with geosmin-related off-flavor in catfish aquaculture are Anabaena, Aphanizomenon and Lyngbya. ${ }^{34}$ Also in trout farming systems in UK, a geosmin-producing species of Oscillatoria has been associated with an earthy taint in cultured pangus.

Based on the distribution and abundance of microphytes, AGPI values of pangasius catfish ponds in three upazila were calculated.
AGPI is also known as algal palmer index that is established as a rapid, reliable and inexpensive method to evaluate the organic pollution level of a water body. ${ }^{35}$ The AGPI values ranged from 17.33 to 25.33 with lowest in ponds located at Sadar and highest in those located at Trishal upazila. Therefore, ponds in Trishal upazila fall into 'high organic pollution' category while ponds in Sadar and Muktagachha were in 'probable high organic pollution' category. Khan et al. ${ }^{36}$ reported that several contiguous ancient ponds in Noakhali district of Bangladesh had AGPI values as high as 27 , while Das et al. reported high values for wastewater fed urban fish ponds in Bankura, India. These results together with water-sediment parameters suggest that pangasius catfish ponds has high supply of nutrients, probably arising from un-used feed and fish feces deposited at the bottom, resulting in heightened level of pollution. ${ }^{37}$

\section{Conclusion}

Major water quality parameters and sediment organic carbon in intensive pangasius catfish culture areas of Mymensingh area of Bangladesh were studied to correlate them to off-flavor producing phytoplankton. It revealed culture ponds under investigation in Trishal upazila had significantly higher level of nutrient compared to Sadar and Muktagachha upazila. These ponds were also judged to be the ponds with 'high organic pollution', based on Algal Genus Pollution Index (AGPI). It may be predicted that the risk of off-flavor production in these ponds was very high. Fish farmers can, therefore, easily use this tool to calculate AGPI of their culture ponds and take appropriate steps like increased water exchange, artificial oxidizing of the sediments to minimize off-flavor in fish before they are harvested. This would ensure profitability of fish farmer in one hand, and benefit the consumers on the other.

\section{Acknowledgments}

The authors gratefully acknowledge the cordial help from pangasius catfish farmers who allowed to collect samples from their culture ponds.

\section{Conflicts of interest}

The author declares that there are no conflicts of interest.

\section{Funding}

None.

\section{References}

1. Thilsted SH, Thorne-Lyman A, Webb P, et al. Sustaining healthy diets: The role of capture fisheries and aquaculture for improving nutrition in the post2015 era. Food Policy. 2016;61:126-131.

2. Sampantamit T, Ho L, Lachat C. Aquaculture Production and Its Environmental Sustainability in Thailand: Challenges and Potential Solutions. Sustainability. 2020;12(5):2010.

3. Tucker CS, van der Ploeg M. Management of off-flavors in channel catfish ponds. Fact Sheet 192, Southern Regional Aquaculture Center, Stoneville, Mississippi, USA. 1999.

4. Smith JL, Boyer GL, Zimba PV. A review of cyanobacterial odorous and bioactive metabolites: impacts and management alternatives in aquaculture. Aquaculture. 2008;280(1-4):5-20.

5. Schrader KK, Rimando AM. Off-flavors in aquaculture: An overview. In: Off-Flavors in Aquaculture. Rimando AM, Schrader KK, editors. ACS Symposium Series 848, American Chemical Society, Washington. 2003:112.

6. King JT Dew. Off-Flavors in Aquaculture. Pages 31-34 in Schrader KK, Rimando AM Am Chem Soc. Washington, DC. 2003. 
7. Aschner M, C Laventer, I Chorin-Kirsch. Off-flavor in carp from fish ponds in the coastal plain and the Gelid. Bamidgeh. 1969;19: 23-25.

8. Lovell RT, Sackey LA. Off-flavor in channel catfish from commercial ponds Trans. Am Fish Soc. 1973;4:774-777.

9. Lovell RT, Broce D. Cause of musty flavor in pond-cultured penaeid shrimp. Aquaculture. 1985;985;50:169-174.

10. Yamprayoon J, Noomhorm AJ. (Geosmin and off -flavor in Nile tilapia (Oreochromis niloticus). Aquat Food Prod Technol. 2000;9: 29-41.

11. From J, Horlyck V. Sites of uptake of geosmin, a cause of earthy-flavor in rainbow trout (Salmo gairdneri). Canadian Journal of Fish Aquaculture. Scienc. 1984;41(8):1224-1226.

12. Izaguirre G, Taylor WD. Geosmin and 2-methylisoborneol production in a major aqueduct system. Water Science and Technology. 1995;31(11):41-48.

13. Jüttner F, Watson SB. Biochemical and ecological control of geosmin and 2-methylisoborneol in source waters. Applied and Environmental Microbiology. 2007;73:4395-4406.

14. Lovell RT. Absorption of earthy-musty flavour by channel catfish held in monospecies cultures of geosmin-producing blue-green algae. Tran Am Fish Soc. 1972;102:775-777.

15. DoF. Yearbook of Fisheries Statistics of Bangladesh, 2017-18. Fisheries Resources Survey System (FRSS), Department of Fisheries. Bangladesh: Ministry of Fisheries, 2018. 35: p. 129.

16. Wang M, Lu M. Tilapia polyculture: a global review. Aquaculture Research. 2016;47(8):2363-2374.

17. Ferdous J, Reza MS, Khan MNA, et al. Effects of water treatment chemicals on plankton biomass in aquaculture. Journal of Agroforestry and Environment. 2013;7(1):65-70.

18. Palmer CM. Composite rating of algae tolerating organic pollution. $J$ Phycol. 1969;5:78-82

19. De Silva SS, Phuong NT. Striped catfish farming in the Mekong Delta, Vietnam: A tumultuous path to a global success. Rev. Aquacult. 2011;3(2):45-73

20. Roy K. Effects on stocking density on the growth of crops in ponds. MS Thesis. Department of Aquaculture, BAU, Mymensingh. 2001;72.

21. Hossain MA, Sarker AK, Amin MN, et al. Development and performance evaluation of sludge remover for intensive aquaculture. Aquacultural Engineering. 2016;74:62-69.

22. Sun X, Ren G, You Q, et al. Global diurnal temperature range (DTR) changes since 1901. Climate Dynamics. 2019;52:3343-3356.

23. Makori AJ, Abuom PO, Kapiyo R. et al. Effects of water physicochemical parameters on tilapia (Oreochromis niloticus) growth in earthen ponds in Teso North Sub-County, Busia County. Fish Aquatic Sci. 2017;20:30.
24. Munsiri P, Boyd C, Hajek B. Physical and chemical characteristics of bottom soil profiles in ponds at Auburn, Alabama, USA and a proposed system for describing pond soil horizons. J World Aquacult Soc. 1995;26:346-377.

25. Downing JA, Cole JJ, Middelburg JJ, et al. Sediment organic carbon burial in agriculturally eutrophic impoundments over the last century. Global Biogeochem Cy. 2008;22:1-10.

26. Haque MM. Emerging Pangasius Aquaculture Dialogue (PAD) Standards: Can Bangladesh Comply with? Paper presentedin the workshop on Pangasius Aquaculture Dialogue (PAD) at ARD Lab, Central Library, Bangladesh Agricultural University, Mymensingh. 22 August 2009. 45p.

27. Boyd CE. Bottom soils, sediment and pond aquaculture. Chapman and Hall, New York, New York, USA. 1995.

28. Mayer $\mathrm{T}$, Telford $\mathrm{S}$ The role of dynamics of sediments in nutrient dynamics of point pleemarsh. In: Proc. $3 e$ Conf 18 Int. Assoc. Great Lakes Res. 1995;p.108.

29. Gilbert PJ, Taylor S, Cooke DA, et al. Variations in sediment organic carbon among different types of small natural ponds along Druridge Bay, Northumberland, UK. Inland Waters. 2014;4(1):57-64.

30. Mccormick PV, C Airns J. Algae as indicators of environmental change. Journal of Applied Phycology. 1994;6:509-526.

31. Saha SB, Bhattacharya SB, Choudhury A. Diversity of phytoplankton of sewage pollution brackish water tidal ecosystems. J Environ Biol. 2000;21(1):9-14.

32. Rashid J, Kobiyama A, Reza MS, et al. Seasonal changes in the communities of photosynthetic picoeukaryotes in Ofunato Bay as revealed by shotgun metagenomic sequencing. Gene. 2018;665:127-132.

33. Zhang T, Zheng L, Li L, et al. 2-Methylisoborneol production characteristics of Pseudanabaena sp. FACHB 1277 isolated from Xionghe Reservoir, China. Journal of Applied Phycology. 2016;28:3353-3362.

34. Schrader KK, Blevins WT. Geosmin-producing species of Streptomyces and Lyngbya from aquaculture ponds. Canadian Journal of Microbiology. 1993;39(9):834-840.

35. Salem Z, Ghobara M, El Nahrawy AA. Spatio-temporal evaluation of the surface water quality in the middle Nile Delta using Palmer's algal pollution index. Egypt. J Basic Appl Sci. 2017;4(3):219-226.

36. Khan NS, Uddin A, Bari JBA, et al. Evaluation the potentiality of ancient ponds by Palmer's algal pollution index, Noakhali, Bangladesh. International Journal of Fisheries and Aquatic Research. 2019;4(4):28-31.

37. Da CT. Evaluation of locally available feed resources for striped catfish (Pangasianodon hypophthalmus). Acta Universitatis Agriculturae Sueciae. $2012 ; 89$. 